\title{
HDAC5 wt Allele
}

National Cancer Institute

\section{Source}

National Cancer Institute. HDAC5 wt Allele. NCI Thesaurus. Code C49395.

Human HDAC5 wild-type allele is located within $17 \mathrm{q} 21$ and is approximately $47 \mathrm{~kb}$ in

length. This allele, which encodes histone deacetylase 5 protein, plays a role in the deacetylation of lysine residues on the $\mathrm{N}$-terminal region of the core histones $\mathrm{H} 2 \mathrm{~A}, \mathrm{H} 2 \mathrm{~B}$, $\mathrm{H} 3$ and $\mathrm{H} 4$. It is also involved in transcriptional repression of myocyte enhancer MEF2C. 